\title{
Analisis Faktor-Faktor yang Mempengaruhi Pertumbuhan Ekonomi pada 15 Negara OKI Tahun 2014-2018
}

\author{
Ira Humaira Hany \\ Mahasiswa Program Studi S2 Ekonomi Islam Fakultas Ekonomi dan Bisnis Universitas \\ Airlangga \\ e-mail: ira.humaira.hany-2018@pasca.unair.ac.id
}

\begin{abstract}
Economic growth is an important factor in measuring how successful the economy is. Therefore, many countries will always try to increase their economic growth for priority targets that must be achieved. This study aims to analyze the factors that influence economic growth in OIC member countries, which consists of 15 countries, namely Afghanistan, Bahrain, Balangdesh, Egypt, Indonesia, Jordan, Kazakhstan, Kuwait, Libya, Malaysia, Morocco, Pakistan, Tunisia, Saudi Arabia and Yemen. This study consists of five variables, namely: GDP, Investment, Exports, Imports, and Government Expenditure using panel data regression analysis. The results showed that three of the four variables used to significantly influence economic growth in OIC countries were exports, imports, and government expenditure, while the investment variable had no significant effect. From this study it can be concluded that not all variables have a significant effect on economic growth in OIC countries.
\end{abstract}

Keywords: economic growth, export, import, investment, government expenditure

\begin{abstract}
Abstrak
Pertumbuhan ekonomi menjadi faktor penting untuk mengukur seberapa sukses keadaan ekonomi. Oleh karena itu, banyak negara akan selalu berusaha untuk meningkatkan pertumbuhan ekonomi mereka untuk target prioritas yang harus dicapai. Penelitian ini bertujuan untuk menganalisis faktor-faktor yang mempengaruhi pertumbuhan ekonomi di negara-negara anggota OKI, yang terdiri dari 15 negara yakni Afghanistan, Bahrain, Bangladesh, Mesir, Indonesia, Jordania, Kazakhstan, Kuwait, Libya, Malaysia, Maroko, Pakistan, Tunisia, Arab Saudi, dan Yaman. Penelitian ini terdiri dari lima variabel, yaitu: GDP, Investasi, Ekspor, Impor, dan Government Expenditure dengan menggunakan analisis regresi data panel. Hasil penelitian menunjukkan bahwa tiga dari keempat variabel yang digunakan secara signifikan mempengaruhi pertumbuhan ekonomi di negara-negara OKI adalah ekspor, impor, dan government expenditure sedangkan variabel investasi, tidak berpengaruh signifikan. Dari penelitian ini dapat disimpulkan bahwa tidak semua variabel berpengaruh signifikan terhadap pertumbuhan ekonomi di negara-negara OKI.
\end{abstract}

Kata kunci: pertumbuhan ekonomi, ekspor, impor, investasi, pengeluaran pemerintah 


\section{PENDAHULUAN}

Pertumbuhan ekonomi merupakan hal yang sangat penting untuk suatu negara. Suatu negara dalam kondisi baik atau tidak salah satu faktornya adalah dengan melihat keadaan ekonomi suatu negara atau dengan kata lain dapat dinilai pada pertumbuhan ekonomi negara tersebut. Pertumbuhan ekonomi merupakan proses perubahan kondisi perekonomian suatu negara secara berkesinambungan menuju keadaan yang lebih baik selama periode tertentu. Suatu negara membutuhkan rencana dan strategi untuk menumbuhkan ekonomi yang diharapkan. Namun demikian, tidak semua negara dapat mencapai pertumbuhan ekonomi seperti yang diharapkan. Oleh karena itu, dibutuhkan analisis beberapa faktor yang mempengaruhi pertumbuhan suatu negara salah satunya adalah kerjasama ekonomi antar negara.

Organisasi Kerjasama Islam (OKI) adalah organisasi dengan jumlah anggota terbanyak setelah organisasi Perserikatan Bangsa-Bangsa (PBB). OKI berdiri pada tanggal 25 September 1969. Tujuan OKI dibentuk adalah untuk melindungi dan menjaga kepentingan anggota (umat Islam) guna mencapai perdamaian dunia. OKI telah berperan dalam memperkuat kerjasama ekonomi dan perdagangan untuk mewujudkan integrasi ekonomi global. Sebanyak 57 negara yang telah bergabung dalam organisasi ini, dimana negara anggota merupakan negara yang mayoritas penduduknya beragama Islam. Negara anggota OKI dikategorisasi berdasarkan tingkat GDP per kapita setiap negara. Tabel 1 menyajikan kategori negara anggota OKI yang terbagi dalam empat kelompok yakni negara berpendapatan rendah, menengahbawah, menengah-atas, dan tinggi.

Kontribusi OKI pada bidang ekonomi yaitu bertujuan untuk memperkuat kerjasama ekonomi dan perdagangan dalam rangka mencapai integrasi ekonomi yang mengarah kepada pembentukan Islamic Common Market. Berdasarkan hal tersebut, dibentuklah Economic and Commercial Cooperation of the OIC (COMCEC) pada Islamic Summit Conference pada Januari 1981. COMCEC menindaklanjuti pelaksanaan resolusi di bidang ekonomi dan bidang perdagangan, mengeksplorasi kemungkinan cara memperkuat kerjasama antar negara-negara anggota, dan mempersiapkan program yang mampu meningkatkan kapasitas ekonomi di daerah-daerah (www.sesric.org).

Berdasarkan latar belakang penelitian, maka penelitian ini bertujuan untuk menguji apakah variabel-variabel eksogen (investasi, ekspor, impor dan government expenditure) mampu menjelaskan variabel endogen (pertumbuhan ekonomi/GDP). Selain itu, penelitian ini juga bertujuan untuk menguji variabel yang memiliki kontribusi/pengaruh terbesar pada pertumbuhan ekonomi pada 15 negara $\mathrm{OKI}$.

Tabel 1. Kelompok Negara OKI Berdasarkan Tingkat Pendapatan Nasional

\begin{tabular}{ll}
\hline \multicolumn{1}{c}{ Kategori } & \multicolumn{1}{c}{ Anggota OKI } \\
\hline $\begin{array}{l}\text { Berpendapatan Rendah (Kurang dari 1.045 } \\
\text { USD) }\end{array}$ & $\begin{array}{l}\text { Mozambik, Niger, Sierra Lione, Afganistan, Togo, Uganda, } \\
\text { Burkina Faso, The Gambia, Sudan, Tajikistan, Guinea-Bissau, } \\
\text { Guinea, Comoros, Benin, Yaman. }\end{array}$ \\
\hline $\begin{array}{l}\text { Kelompok Negara OKI Berpendapatan } \\
\text { Menengah Bawah (1.046 USD-4.125 USD) }\end{array}$ & $\begin{array}{l}\text { Kirgizstan, Mauritania, Uzbekistan, Pakistan, Kamerun, } \\
\text { Bangladesh, cote d'Ivoire, Mesir, Moroko, Tunisia, Indonesia. }\end{array}$ \\
\hline Kelompok Negara OKI Berpendapatan & Algeria, Azerbaijan, Guyana, Iran, Suriname, Libya, \\
Menengah Atas (4.126 USD-12.735 USD) & Turkmenistan, Gabon, Turki, Kazakhstan, Malaysia, Lebanon \\
\hline $\begin{array}{l}\text { Kelompok Negara OKI Berpendapatan } \\
\text { Tinggi (Lebih dari 12.736 USD) }\end{array}$ & $\begin{array}{l}\text { Oman, Arab Saudi, Bahrain, Kuwait, Brunei Darussalam, Uni } \\
\text { Emirates Arab, Qatar }\end{array}$ \\
\hline
\end{tabular}

Sumber: https://isdbdata.github.oi/mc 


\section{Pertumbuhan Ekonomi}

Menurut Adisasmita (2013), pertumbuhan ekonomi adalah upaya peningkatan kapasitas produksi untuk menghasilkan penambahan output. Dengan kata lain, pertumbuhan ekonomi merupakan proses bertambahnya output perkapita dalam jangka panjang. Fokusnya ada pada tiga aspek, yakni proses, output perkapita, dan jangka panjang. Pertumbuhan ekonomi bukan suatu gambaran ekonomi pada suatu saat melainkan adalah suatu proses. Oleh karena itu, dapat dikatakan bahwa pertumbuhan ekonomi bersifat dinamis, suatu perekonomian dapat berkembang dan berubah seiring waktu. Tekanannya pada perubahan atau pekembangan itu sendiri. Pertumbuhan ekonomi dapat diukur dengan Produk Domestik Bruto (PDB) maupun Produk Domestik Regional Bruto (PDRB) dalam suatu wilayah/negara.

\section{Investasi}

Investasi adalah bentuk pengeluaran sejumlah dana dari pihak investor (penanam modal) dalam rangka membiayai kegiatan produksi untuk memperoleh keuntungan di masa depan. Investasi dapat terjadi dari kegiatan penanaman modal baik secara langsung maupun tidak langsung dari berbagai pihak untuk meningkatkan output. Tidak hanya output, akan tetapi investasi juga untuk menentukan distribusi tenaga kerja dan distribusi pendapatan, pertumbuhan dan kualitas penduduk serta teknologi. Tingkat investasi yang tinggi akan meningkatkan kapasitas produksi yang pada akhirnya berujung pada pembukaan lapangan kerja baru. Adanya investasi juga memungkinkan terjadinya transfer teknologi dan pengetahuan dari negara maju ke negara berkembang.

Pada penelitian terdahulu yang dilakukan oleh Nguyen (2018) dengan judul "The impacts of public investment on private investment and economic growth." Hasil dari penelitiannya menunjukkan bahwa investasi publik di Vietnam pada masa lalu tidak mempengaruhi pertumbuhan ekonomi dalam pola bentuk U-terbalik sebagaimana yang ditemukan Barro (1990), dengan efek positif sebagian besar terjadi sejak tahun kedua dan efek negatif dari menghambat pertumbuhan jangka panjang. Sementara itu, investasi dari sektor swasta, perusahaan milik negara, dan FDI memiliki efek positif pada jangka pendek pertumbuhan ekonomi dan persediaan modal milik negara memiliki dampak positif pada pertumbuhan ekonomi dalam jangka pendek dan jangka panjang. Diperkirakan pengaruh investasi publik pada investasi swasta juga menunjukkan hal yang serupa bentuk terbalik-U di mana investasi publik memiliki crowding-in investasi swasta jangka pendek tetapi dalam jangka Panjang crowding-out (Nguyen, 2018).

\section{Ekspor dan Impor}

Ekspor impor merupakan bagian dari perdagangan Internasional, dimana perdagangan internasional tidak lepas dengan yang namanya supply and demand antar negara. Guna untuk memenuhi kebutuhan di suatu negara, dilakukanlah kegiatan ekspor dan impor. Ekspor adalah penjualan barang ke luar negeri dengan menggunakan sistem pembayaran, kualitas, kuantitas, dan syarat penjualan lainnya yang telah disetujui oleh pihak eksportir dan importir. Permintaan ekspor adalah jumlah barang/jasa yang diminta untuk diekspor dari suatu negara ke negara lain (Sukirno, 2010). Impor adalah kegiatan memasukkan barang ke dalam daerah pabean. Transaksi impor adalah perdagangan dengan cara memasukkan barang dari luar negeri ke dalam daerah pabean Indonesia dengan mematuhi ketentuan peraturan perudangundangan yang berlaku (Tanjung, 2011).

\section{Government Expenditure}

Pengeluaran pemerintah merupakan indikator besarnya kegiatan pemerintah yang dibiayai oleh pengeluaran pemerintah. 
Semakin besar dan banyak kegiatan pemerintah semakin besar pula pengeluaran pemerintah yang bersangkutan. Dalam beberapa penelitian terdahulu, kebijakan belanja atau pengeluaran pemerintah terbukti secara empiris memiliki pengaruh atau dampak terhadap pertumbuhan ekonomi baik dalam skala nasional maupun daerah. Begitu pula dalam model hubungan timbal balik, pertumbuhan ekonomi juga dapat memberikan dampak terhadap tingkat pengeluaran pemerintah. Pengeluaran pemerintah mengacu pada dasar teori keseimbangan pendapatan nasional, yakni $\mathrm{Y}=\mathrm{C}+\mathrm{I}+\mathrm{G}+(\mathrm{X}-\mathrm{M})$. Formula dari dasar teori tersebut adalah legitimasi pandangan kaum Keynesian bahwa terdapat campur tangan pemerintah dalam perekonomian. Selain itu, formula tersebut dapat dilihat bahwa pengeluaran pemerintah berbanding lurus dengan pendapatan nasional. Penelitian yang dilakukan oleh Cullison (1993) menyatakan bahwa pengeluaran pemerintah untuk pendidikan dan pelatihan tenaga kerja memiliki pengaruh signifikan yang berdampak pada pertumbuhan ekonomi masa depan.

Berdasarkan kajian literatur tersebut, maka penelitian ini mengajukan hipotesis sebagai berikut:

H1: Investasi berpengaruh terhadap pertumbuhan ekonomi

H2: Ekspor berpengaruh terhadap pertumbuhan ekonomi

H3: Impor berpengaruh terhadap pertumbuhan ekonomi

H4: Government Expenditure berpengaruh terhadap pertumbuhan ekonomi
Gambar 1. Kerangka Penelitian

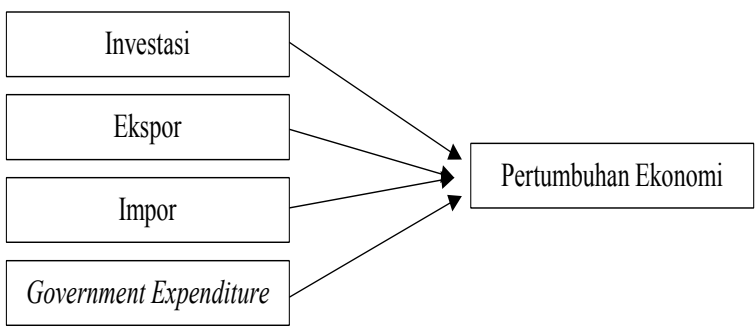

\section{METODE PENELITIAN}

Jenis data yang digunakan dalam penelitian ini adalah data sekunder. Penelitian ini menggunakan pendekatan eksplanatif yang bertujuan untuk menjelaskan hubungan antar variabel dengan melakukan pengujian hipotesis. Data penelitian ini menggunakan data cross section dan time series atau populer disebut data panel. Gujarati (1995) menyatakan bahwa data panel adalah data dari satu atau beberapa variabel yang dikumpul secara berkala dalam kurun waktu tertentu. Penelitian ini menggunakan data time series berupa data kuartal selama lima tahun yaitu dari tahun 2014 sampai 2018. Data cross section yang digunakan meliputi negara anggota OKI yang dikategorikan berdasarkan tingkat pendapatan dari kelompok berpendapatan Tinggi, menengah atas, menengah bawah, dan rendah yaitu Afganistan, Bahrain, Bangladesh, Mesir, Indonesia, Yordania, Kazakhstan, Kuwait, Libya, Malaysia, Maroko, Pakistan, Tunisia, Arab Saudi, dan Yaman. Dalam mengaplikasikan data panel, dapat menggunakan metode regresi data panel. Secara umum model regresi data panel dapat dilakukan dalam tiga pendekatan, yakni pendekatan common effect, random effect, dan pendekatan fixed effect. Salah satu dari tiga pendekatan tersebut perlu dipilih dalam pengujian regresi data panel. Pendekatan yang dipilih adalah pendekatan yang menghasilkan model yang signifikan. Model regresi yang baik harus didasarkan pada pengujian hipotesis. 
Hipotesis Uji Chow dalam penelitian ini yakni:

\section{H0: Common Effect Model (CEM) \\ H1: Fixed Effect Model (FEM)}

Dengan ketentuan jika probabilitas diatas 0.05 maka H0 diterima, sehingga model yang digunakan adalah common effect. Namun jika probabilitas bawah 0.05 H0 ditolak dan H1 diterima, maka model yang digunakan adalah fixed effect.

Hipotesis Uji Hausman dalam penelitian ini yakni:

\section{H0: Random Effect Model (REM)}

\section{H1: Fixed Effect Model (FEM)}

Dengan ketentuan jika probabilitas di atas 0.05 maka $\mathrm{H} 0$ diterima, sehingga model yang digunakan adalah Random Effect. Namun jika probabilitas bawah $0.05 \mathrm{HO}$ ditolak dan $\mathrm{H} 1$ diterima, maka model yang digunakan adalah fixed effect.

Hipotesis Uji Lagrange Multiplier dalam penelitian ini yakni:

\section{H0: Random Effect Model (REM) \\ H1: Common Effect Model (CEM)}

Dengan ketentuan jika probabilitas di atas 0.05 maka $\mathrm{H} 0$ diterima, sehingga model yang digunakan adalah Random Effect. Namun jika probabilitas bawah $0.05 \mathrm{HO}$ ditolak dan $\mathrm{H} 1$ diterima, maka model yang digunakan adalah Common Effect.

Supranto (2001) menyatakan bahwa model regresi data panel juga dikenal sebagai regresi linear berganda yang digunakan untuk menjelaskan hubungan antara variabel dependen dan independen.

Persamaan regresi data panel tersaji pada persamaan (1) berikut.

$$
\mathrm{Y}_{\mathrm{it}}=\alpha+\beta_{1} \mathrm{X}_{1 \mathrm{it}}+\beta_{2} \mathrm{X}_{2 \mathrm{it}}+\ldots \ldots+\beta_{\mathrm{n}} \mathrm{X}_{\mathrm{nit}+} \mathrm{e}_{\mathrm{it}}
$$

Keterangan:

$\mathrm{Y}=$ Variabel Dependen

$\beta=$ Koefisien Variabel Independen

$\mathrm{X}=$ variabel independent

$\mathrm{t}$ = waktu ke $\mathrm{t}$

$\mathrm{i}=$ entitas ke $\mathrm{i}$

$\mathrm{e}=$ variabel error

Terdapat dua tahap yang dilakukan untuk mencapai model terbaik yang akan digunakan dalam penelitian. Tahap pertama dengan pengujian Chow (Chow Test). Tahap ini dilakukan untuk menentukan apakah model yang digunakan termasuk fixed affect atau common effect. Tahap kedua adalah pengujian Hausman (Hausman Test). Pengujian ini dilakukan untuk menentukan apakah model yang dipilih termasuk random effect atau fixed effect. Variabel yang digunakan dalam penelitian ini yakni GDP, Investment, Export, Import, dan Government Expenditure dengan data yang diperoleh melalui https://isdbdata.github.oi/mc

1. Variabel Dependen (Y): Pertumbuhan ekonomi dengan proxy Gross Domestic Product (GDP), yakni pendapatan masing-masing negara anggota OKI selama kurun waktu 2014-2018, sebagai variabel endogen.

2. Variabel Independen (X1): Investment, merupakan investasi yang diperoleh 15 negara OKI dalam kurun waktu 20142018, sebagai variabel eksogen

3. Variabel Independen (X2): Export (EX) yang dilakukan oleh masing-masing 15 negara OKI selama kurun waktu 20142018, sebagai variabel eksogen

4. Variabel Independen (X3): Import (IM) yang dilakukan oleh masing-masing 15 negara OKI selama kurun waktu 20142018, sebagai variabel eksogen.

5. Variabel Independen (X4): Government Expenditure, merupakan belanja atau pengeluaran pemerintah diukur melalui APBN dari masing-masing 15 negara 
OKI selama kurun waktu 2014-2018, sebagai variabel eksogen.

Dalam penelitian ini, menganalisis empat faktor yang mempengaruhi pertumbuhan ekonomi di 15 negara OKI, menggunakan alat analisis metode analisis linear berganda dengan menggunakan data panel, sehingga membentuk persamaan model sebagai berikut ini:

$G D P_{i t}=\alpha+\beta_{1} I N V_{i t}+\beta_{2} E X_{i t}+\beta_{3} I M_{i t}+\beta_{4} G O V_{i t}+e_{i t} 2$

\section{HASIL DAN PEMBAHASAN}

Berdasarkan hasil interpretasi pengolahan data yang menggunakan aplikasi EViews9 dan seperti yang dijelaskan sebelumnya, dalam penelitian ini menggunakan dua uji dari data yang telah dikumpulkan. Hasil uji chow menunjukkan bahwa tingkat probabilitas P-Value atau probabilitas c-square dan uji f sebesar 0.0015 . Dengan demikian, dapat disimpulkan bahwa pada $\alpha=5 \%$ atau 0.05 , maka niai $\mathrm{p}<\alpha$ atau $0.0015<0.05$. Artinya hasil uji menandakan bahwa $\mathrm{H} 0$ ditolak, dan $\mathrm{H} 1$ diterima. Sehingga, model yang dipilih adalah fixed effect model.
Tabel 1. Hasil Uji Chow

\begin{tabular}{lrrr}
\hline \multicolumn{1}{c}{ Effects Test } & \multicolumn{1}{c}{ Statistic } & \multicolumn{1}{c}{ d.f. } & Prob. \\
\hline Cross-section F & 2.381411 & $(14,56)$ & 0.0112 \\
Cross-section & 35.032115 & 14 & 0.0015 \\
Chi-square & & & \\
\hline
\end{tabular}

Selanjutnya, dilakukan uji Hausman p-value atau hasil probabilitas sebesar 0.0000 Dengan tingkat kesalahan $\alpha=5 \%$ atau 0.05 maka $\mathrm{p}$-value $<\alpha$ atau $0.0000<0.05$. Hasil uji menandakan bahwa H0 ditolak, dan H1 diterima. Dengan demikian, model yang tepat digunakan dalam penelitian ini adalah fixed effect model. Hasil uji Hausman dapat diperhatikan melalui Tabel 2, sebagai berikut ini:

Tabel 2. Hasil Uji Hausman

\begin{tabular}{cccc}
\hline Test Summary & $\begin{array}{c}\text { Chi-Sq. } \\
\text { Statistic }\end{array}$ & $\begin{array}{c}\text { Chi- } \\
\text { Sq. d.f. }\end{array}$ & Prob. \\
\hline $\begin{array}{c}\text { Cross-section } \\
\text { random }\end{array}$ & 28.755458 & 4 & 0.0000 \\
\hline
\end{tabular}

Berdasarkan hasil dari uji Chow dan Uji Hausman, maka dapat ditentukan model yang tepat digunakan dalam penelitian ini adalah fixed effect model (FEM). Selanjutnya, data yang telah dikumpulkan akan dianalisis menggunakan regresi yang disajikan pada Tabel 3.

Tabel 3. Hasil Regresi dengan Fixed Effect Model (FEM)

\begin{tabular}{lrrrc}
\hline \multicolumn{1}{c}{ Variable } & Coefficient & \multicolumn{1}{c}{ Std. Error } & t-Statistic & Prob. \\
\hline C & 18.55208 & 5.488681 & 3.380062 & 0.0013 \\
INVESTMENT & 0.261286 & 0.403574 & 0.647431 & 0.5200 \\
EXSPOR & 0.357281 & 0.056053 & 6.374039 & 0.0000 \\
IMPOR & -0.245500 & 0.081517 & -3.011625 & 0.0039 \\
GOVERNMENT EXPENDITURE & -0.643946 & 0.198099 & -3.250623 & 0.0020 \\
\hline & Effects Specification & & \\
Cross-section fixed (dummy variables) & & & & \\
R-squared & 0.724657 & Mean dependent var & & 2.573293 \\
Adjusted R-squared & 0.636155 & S.D. dependent var & & 10.71386 \\
S.E. of regression & 6.462556 & Akaike info criterion & & 6.784457 \\
Sum squared resid & 2338.820 & Schwarz criterion & & 7.371554 \\
Log likelihood & -235.4171 & Hannan-Quinn criter. & 7.018879 \\
F-statistic & 8.187948 & Durbin-Watson stat & 2.881716 \\
Prob(F-statistic) & 0.000000 & & \\
\hline
\end{tabular}


Berdasarkan Tabel 3, hasil uji regresi menggunakan fixed effect model diperoleh data sebagai berikut. Variabel investasi memiliki nilai koefisien sebesar 0.261286 dengan probabilitas sebesar 0.5200 dimana nilai $0.5200>0.05$. Artinya investasi memiliki nilai positif dan tidak signifikan sehingga tidak berpengaruh terhadap pertumbuhan ekonomi. Sementara itu, tiga variabel lain yang digunakan dalam penelitian memiliki pengaruh terhadap pertumbuhan ekonomi. Pertama, variabel ekspor memiliki nilai koefisien sebesar 0.357281 dengan probabilitas 0.0000 , dimana nilai $0.0000<0.05$ memiliki nilai positif dan signifikan. Dengan demikian, jika ekspor meningkat satu persen akan meningkatkan pertumbuhan ekonomi sebesar 0,3572. Kedua, variabel impor memiliki nilai koefisien sebesar -0.245500 dengan probabilitas 0.0039 dimana $0.0039<$ 0.05 . Artinya variabel impor memiliki nilai negatif dan signifikan sehingga jika impor meningkat satu persen maka pertumbuhan ekonomi mengalami penurunan sebesar $-0,2455$. Ketiga, government expenditure memiliki nilai koefisien sebesar -0.643946 dengan probabilitas 0.0020 dimana nilai $0.0020<0.05$. Artinya variabel government expenditure memiliki nilai negatif dan signifikan. Dapat dikatakan bahwa ketika government expenditure meningkat satu persen maka akan menurunkan pertumbuhan ekonomi sebesar -0.6439. Variabel ekspor, impor, dan government expenditure memiliki pengaruh terhadap pertumbuhan ekonomi (GDP).

Berdasarkan Tabel 3 dapat diketahui bahwa uji F statistik sebesar 0.0000. Dimana $0.0000<0.5$, maka variabel eksogen secara bersama-sama dapat menjelaskan variabel endogen. Selanjutnya pada uji R2, mendapatkan nilai sebesar 0.724657 , sehingga dapat dijelaskan bahwa .72 .4657 persen pertumbuhan ekonomi (GDP) dipengaruhi variabel eksogen. Sementara itu,
22.5343 persen dipengaruhi oleh variabel yang lainnya yang tidak disebutkan dalam penelitian ini.

Temuan dalam penelitian ini membenarkan temuan sebelumnya yang ditulis oleh Nguyen (2018) dengan judul "The impacts of public investment on private investment and economic growth." Hasil dari penelitiannya menunjukkan bahwa investasi publik di Vietnam pada masa lalu tidak mempengaruhi pertumbuhan ekonomi dalam pola bentuk U-terbalik. Hasil penelitian ini juga memberikan bukti empiris bahwa investasi tidak berpengaruh terhadap pertumbuhan ekonomi.

Selanjutnya, ekspor, impor, dan government expenditure berpengaruh terhadap pertumbuhan ekonomi. Masingmasing hasil temuan tersebut didukung oleh penelitian terdahulu, yakni penelitian yang dilakukan oleh (Hye, 2012) yang menyebutkan bahwa ekspor dan impor berpengaruh terhadap pertumbuhan ekonomi, dan dalam penelitian Hye (2012) ini secara parsial pertumbuhan ekonomi dan pengeluaran pemerintah juga memiliki hubungan yang signifikan dengan arah positif. Terdapat pengaruh yang signifikan antara pertumbuhan ekonomi dengan pengeluaran pemerintah di 14 negara OKI. Apabila pertumbuhan ekonomi meningkat maka pengeluaran pemerintah juga akan naik. Begitu juga sebaliknya, apabila pertumbuhan ekonomi menurun maka pengeluaran pemerintah akan turun, dimana adanya perubahan pengeluaran pemerintah dipengaruhi oleh beberapa faktor salah satunya yakni pertumbuhan ekonomi yang dapat diukur dengan pendapatan perkapita, makin besar pendapatan perkapita masyarakat maka pengeluaran pemerintah juga semakin besar, hal ini dapat terjadi karena tingkat pendapatan perkapita semakin besar maka akan terjadi perubahan struktur kebutuhan masyarakat yang lebih tinggi sehingga modal yang besarpun dikeluarkan untuk 
memenuhi tingginya kebutuhan masyarakat. Berikutnya juga dijelaskan dalam penelitian yang dilakukan oleh Cullison (1993) berpendapat bahwa pengeluaran pemerintah (government expenditure) untuk pendidikan dan pelatihan tenaga kerja memiliki tidak berdampak signifikan pada pertumbuhan ekonomi. Selanjutnya penelitian yang ditulis oleh Setya Wira Perdana (2018). Temuan yang didapat dari hasil regresi penelitian tesebut adalah variabel belanja pendidikan berpengaruh signifikan namun negatif terhadap pertumbuhan ekonomi.

\section{SIMPULAN DAN SARAN}

Berdasarkan hasil penelitian yang telah dilakukan dapat disimpulkan bahwa investasi tidak berpengaruh terhadap pertumbuhan ekonomi. Di sisi lain, ekspor, impor, dan government expenditure berpengaruh pada pertumbuhan ekonomi. Pertumbuhan ekonomi pada Negara OKI dapat diukur dengan berbagai indikator yang ada. Oleh karena itu diharapkan penelitian dapat menggunakan indikator-indikator lain, guna mendapatkan hasil yang lebih baik. Penelitian ini menganalisis pertumbuhan ekonomi pada 15 negara yang tergabung dalam OKI. Penelitian selanjutnya dapat melakukan analisis pada konteks negara berbeda.

\section{REFERENSI}

Adisasmita, R. (2013). Teori Pembangunan Ekonomi, Pertumbuhan Ekonomi dan Pertumbuhan Wilayah. Yogyakarta: Graha Ilmu.

Barro, R. J. (1990). Government spending in a simple model of endogeneous growth. Journal of political economy, 98(5, Part 2), S103-S125.

Cullison, W. (1993). Public investment and economic growth. FRB Richmond Economic Quarterly, 79(4), 19-33.
Gujarati, D. (1995). Ekonometrika Dasar. Jakarta: Erlangga.

https://isdbdata.github.oi/mc

https://sesric.org/

Hye, Q. M. A. (2012). Exports, imports and economic growth in China: an ARDL analysis. Journal of Chinese Economic and Foreign Trade Studies.

Nguyen, C. T., \& Trinh, L. T. (2018). The impacts of public investment on private investment and economic growth. Journal of Asian Business and Economic Studies.

Perdana, Setya Wira. (2018). Analisi Pengaruh Pengeluaran Pemerintah dan Investasi Terhadap Pertumbuhan Ekonomi di Provinsi Jawa Timur. Jurnal Ilmiah Mahasiswa Fakultas Ekonomi dan Bisnis, Vol. 6, No. 2.

Sukirno, S. (2010). Makro Ekonomi: Teori Pengantar. Jakarta: Rajawali Press.

Supranto. (2001). Statistik Teori dan Aplikasi. Jakarta: Erlangga.

Tanjung, M. (2011). Aspek dan Prosedur Ekspor-Impor. Jakarta: Salemba Empat. 